\title{
EFEKTIVITAS PERATURAN MENTERI DALAM NEGERI NOMOR 2 TAHUN 2014
}

\author{
Harun Al Rosyid \\ Magister Ilmu Hukum Universitas Islam Malang \\ Email : harun.al5@gmail.com
}

\begin{abstract}
Abstrak
Dalam rangka sebagai upaya untuk mewujudkan efektifitas pengelolaan jaringan dokumentasi dan informasi hukum, tentunya sangat diperlukan pembinaan dan pengawasan, untuk itu maka telah dituangkan ke dalam pasal 12 Peraturan Menteri Dalam Negeri Republik Indonesia Nomor 2 Tahun 2014 tentang Pengelolaan Jaringan Dokumentasi dan Informasi Hukum Kementrian Dalam Negeri dan Pemerintah Daerah.
\end{abstract}

Kata kunci: efektifitas, pengelolaan jaringan, pemerintahan daerah

\begin{abstract}
In order as an effort to realize the effectiveness of the management of legal documentation and information networks, of course coaching and supervision is needed, for this reason it has been stated in Article 12 of the Republic of Indonesia Minister of Home Affairs Regulation No. 2 of 2014 concerning Management of the Ministry of Home Affairs Legal Documentation and Information Network and Regional Government.
\end{abstract}

Keywords: effectiveness, network management, regional government

\section{PENDAHULUAN}

Pemerintahan Daerah adalah penyelenggaraan urusan pemerintahan oleh pemerintah daerah dan dewan perwakilan rakyat daerah menurut asas otonomi dan tugas pembantuan dengan prinsip otonomi seluas-luasnya dalam system dan prinsip Negara kesatuan republic Indonesia sebagaimana dimaksud dalam undang-undang dasar. Otonomi daerah adalah hak, wewenang daerah dan kewajiban daerah otonom untuk mengatur dan mengurus sendiri urusan pemerintahan dan kepentingan masyarakat setempat dalam system Negara Kesatuan Republik Indonesia.

Dengan adanya pembagian pembagian daerah Indonesia atas daerah besar dan kecil, dengan bentuk dan susunan pemerintahannya di tetapkan dengan undang-undang, secara anatomis urusan pemerintah di bagi tiga yakni :

1. Urusan Pemerintahan absolut yang merupakan urusan mutlak pemerintah pusat (politik luar ngeri, pertahanan, keamanan, yustisi, monoter dan fiscal nasiolal dan agama),

2. Urusan Pemerintahan Konkuren adalah urusan pemerintahan yang di bagi antara pemerintah pusat dan daerah propinsi dan daerah kabupaten/kota, urusan pemerintahan konkuren yang di serahkan ke daerah yang menjadi dasar pelaksanaan otonomi daerah yang terdiri atas urusan pemerintahan wajib dan urusan pemerintahan pilihan. 


\section{$\mathcal{H}$ urnal Negara dan Keadilan \\ p-ISSN 2302-7010 e-ISSN 2721-9801}

3. Urusan Pemerintahan Umum adalah urusan Pemerintahan yang menjadi kewenangan

Presiden sebagai kepala pemerintahan Urusan yang menjadi kewenangan daerah terdiri atas urusan pemerintahan wajib dan urusan pemerintahan pilihan, urusan pemerintahan wajib terdiri atas urusan pemerintahan yang berkaitan dengan pelayanan dasar dan urusan pemerintahan yang tidak berkaitan dengan pelayanan dasar. Urusan pemerintahan wajib yang berkaitan dengan pelayanan dasar adalah urusan pemerintahan wajib yang sebagian substansinya merupakan pelayanan dasar yang meliputi Pendidikan, kesehatan, pekerjaan umum dan penataan ruang, perumahan rakyat dan kawasan permukiman, ketentraman, ketertiban umum dan perlindungan masyarakat dan social.

Sedangkan urusan pemerintahan wajib yang tidak berkaitan dengan pelayanan dasar meliputi : tenaga kerja, pemberdayaan perempuan dan perlindungan anak, pangan, pertanahan, lingkungan hidup, administrasi kependudukan dan catatan sipil, pemberdayaan masyarakat dan desa, pengendalian penduduk dan keluarga berencana, perhubungan, komunikasi dan informatika, koperasi, usaha kecil dan menengah, penanaman modal, kepemudaan dan oleh raga, statistic, persandian, kebudayaan, perpustakaan dan kearsipan.

Adapun urusan pemerintahan pilihan meliputi Kelautan dan perikanan, pariwisata, pertanian, kehutanan, energy dan sumberdaya mineral, perdagangan, perindustrian, dan transmigrasi. Urusan pemerintahan wajib terdiri atas urusan pemerintahan yang berkaitan dengan pelayanan dasar dan urusan pemerintahan yang tidak berkaitan dengan pelayanan dasar.

Dalam melaksanakan otonomi daerah saat ini telah memasuki era baru yang mana presiden dan DPR telah sepakat untuk mengesahkan undang-undang nomor 23 tahuan 2014 tentang pemerintahan daerah sebagaimana telah diubah beberapa kali yang terakhir kalinya dengan Undang-undang Nomor 9 Tahun 2014 tentang pemerintahan daerah.

Sejalan dengan berlakunya undang-undang nomor 23 tahuan 2014 tentang pemerintahan daerah, pemerintah telah memberikan kewenangan yang lebih luas, nyata dan bertanggung jawab. Dengan demikian diharapkan masing-masing daerah akan dapat lebih membangunnya daerah masing-masing dengan maju, mandiri, sejahtera dan kopetitif di dalam pelaksanaan pemerintahan maupun dalam pembangunan daerahnya masing-masing. Memang harapan dan kenyataan tidak lain akan selalu sejalan, tujuan atau harapan tentu akan berakhir baik bila pelaksanaan dan pengawasan terhadap pelaksanaan juga berjalan baik. Namun ketidak ketercapaian harapan itu nampaknya mulai terlihat dalam otonomi daerah yang ada di Indonesia. Masih banyak permasalahan yang mengiringi berjalanya otonomi daerah di Indonesia. Permasalahan-permasalahan itu tentu harus dicari penyelesaianya agar tujuan dari otonomi daerah dapat tercapai.

Sejak diberlakukanya Undang-undang mengenai otonomi daerah, banyak orang sering membicarakan aspek positifnya. Memang tidak disangkal lagi bahwa otonomi daerah membawa perubahan positif di daerah dalam hal kewenangan daerah untuk mengatur diri sendiri, kewenangan ini menjadi sebuah impian karena sistim pemerintahan yang sentralistik cenderung menempatkan daerah sebagai pelaku pembangunan yang begitu penting atau pembangunan mengutamakan dari pinggiran, daerah justru mengalami proses pengentasan kemiskinan yang luar biasa, dengan kewenangan tersebut tampaknya banyak daerah yang optimis bakal 


\section{Zurnal Negara dan $\mathcal{X}$ eadilan \\ p-ISSN 2302-7010 e-ISSN 2721-9801}

bisa mengubah keadaan yang menguntungkan, akan tetapi apakah di tengahtengah optimisme itu tidak terbesit kekhawatiran bahwa otonomi daerah juga akan menimbulkan beberapa persoalan yang jika tidak segera di cari pemecahanya, akan menyulitkan upaya daerah untuk memajukan rakyatnya. Jika jawabanya tidak, tentu akan sangat na'if, karena tanpa disadari beberapa dampak yang tidak menguntukngkan bagi pelaksanaan otonomi daerah telah terjadi.

Ada beberapa permasalahan yang dikhawatirkan bila dibiarkan berkepanjangan akan berdampak sangat buruk pada susunan ketatanegaraan Indonesia.

a. Pemahaman terhadap konsep desentralisasi dan otonomi daerah yang belum mantap

b. Penyediaan aturan pelaksanaan otonomi daerah yang belum memadai

c. Kondisi SDM aparatur pemerintahan yang belum menunjang sepenuhnya pelaksanaan otonomi daerah

d. Adanya potensi munculnya konflik antar daerah.

Permasalahan tersebut merupakan tantangan bagi penyelenggara pemerintahan daerah untuk membuktikan bahwa otonomi daerah dapat berjalan dengan baik dengan prinsip pemerintahan yang baik (good governance). Adapun yang dimaksud Pemerintahan Daerah adalah penyelenggaraan pemerintahan daerah (pasal 1 angka 2 UU nomor 23 tahun 2014) "Penyelenggaraan urusan pemerintahan oleh pemerintah daerah dan DPRD menurut azas otonomi dan tugas pembantuan dengan prisnip otonomi seluas-luasnya dalam sistim dan prinsip Negara Kesatuan Republik Indonesia sebagaimana dimaksud dalam Undangundang Dasar Negara Republik Indonesia Tahun 1945".

Adapun definisi Pemerintah Daerah (pasal 1 angka 3 UU nomor 23 tahun 2014) "Kepala Daerah sebagai unsur penyelenggara pemerintahan daerah yang memimpin pelaksanaan urusan pemerintahan yang menjadi kewenangan daerah otonom".

Dewan Perwakilan Rakyat Daerah (DPRD) merupakan bagian dari penyelenggara pemerintahan daerah yang turut menentukan bentuk dan hasil pemerintahan daerah yang berlangsung. Hanya saja seberapa jauh peran tersebut dijalankan, akan tetapi sangat bergantung pada kedudukanya ketika diperbandingkan dengan unsur penyalenggara pemerintahan daerah lainya, yaitu kepala daerah ini menunjukan semenjak reformasi kedudukan DPRD telah diperkuat, bahkan pada mulanya (berdasarkan UU nomor 22 tahun 1999) menjadi dominan terhadap eksekutif. Namun demikian dalam perkembangan mutakhir (UU nomor 32 tahun 2004) kedudukan di antara keduanya diarahkan untuk seimbang atau sederajat.

Dengan demikian karena Undang-undang nomor 32 Tahun 2004 tentang Pemerintahan Daerah tidak sesuai lagi dengan perkembangan keadaan, ketatanegaraan dan tuntutan penyelenggaraan pemerintahan daerah, maka dicabut dengan undang-undang Nomor 23 Tahun 2014 tentang Pemerintahan Daerah, untuk itu guna mewujudkan pengelolaan jaringan dokumentasi informasi hokum yang baik, maka penelitian ini dilakukan.

\section{METODE PENELITIAN}

Penelitian ini merupakan penelitian hokum normative, yang meneliti dan yang menguji norma hukum yang terdapat dalam peraturan perundang-undangan yang terkait dengan pengelolaan jaringan dokumentasi informasi hokum di 


\section{Jurnal Negara dan Keadilan \\ p-ISSN 2302-7010 e-ISSN 2721-9801}

kementrian dalam negeri dan pemerintah daerah, pengelolaan jaringan dokumentasi informasi hokum merupakan pelaksanaan dari Peraturan Presiden Nomor 33 Tahun 2012 tentang Jaringan Dokumentasi dan Informasi hukum di pemerintah daerah, dan di tindaklanjuti oleh Peraturan menteri Hukum dan Hak Asasi Manusia.

\section{PEMBAHASAN}

Di dalam pasal 4 Peraturan Presiden Republik Indonesia Nomor 33 Tahun 2012 tentang Jaringan Dokumentasi dan Informasi Hukum Nasional berbuyi :

'(1) Organisasi JDIHN terdiri atas :

'a. Pusat JDIHN ;

'b. Anggota JDIHN.

'(2) Badan Pembinaan Hukum Nasional, Kementrian Hukum dan Hak Asasi Manusia merupakan Pusat JDIHN sebagaimana dimaksud pada ayat (1) huruf a.

(3) Anggota JDIHN sebagaimana dimaksud pada ayat (1) huruf b terdiri atas :

'a. Biro hukum dan/atau unit kerja yang tugas dan fungsinya menyelenggarakan kegiatan-kegiatan yang berkaitan dengan dokumen hokum pada :

'1. Kementrian Negara;

'2. Sekretariat Lembaga Negara ;

'3. Lembaga Pemerintahan non Kementrian;

'4. Pemerintah Propinsi ;

'5. Pemerintah Kabupaten/Kota ; dan

'6. Sekretariat Desan Perwakilan Rakyat Daerah tingkat Provinsi dan Kabupaten/Kota.

'b. Perpustakaan hokum pada perguruan tinggi negeri dan perguruan tinggi swasta;

'c. Lembaga lain yang bergerak di bidang pengembangan dokumentasi dan informasi hokum yang ditetapkan oleh menteri.

Dan dalam pasal 5 ayat (2) Peraturan Presiden Republik Indonesia Nomor 33 Tahun 2012 tentang Jaringan Dokumentasi dan Informasi Hukum Nasional berbuyi :

'(2) anggota JDIHN sebagaimana di maksud dalam pasal 4 ayat (3) huruf a angka 1 dan angka 2, bertindak sebagai pusat jaringan dokumentasi dan informasi hukum di lingkunganya.

Dan dalam pasal 7 Peraturan Presiden Republik Indonesia Nomor 33 Tahun 2012 tentang Jaringan Dokumentasi dan Informasi Hukum Nasional berbuyi :

Pusat JDIHN dan Anggota JDIHN sebagaimana dimaksud dalam pasal 4 ayat (2) dan ayat (3) wajib melakukan pengelolaan dokumentasi dan informasi hokum dengan menyediakan sarana dan prasarana serta sumber daya manusia dan anggaran. 


\section{Zurnal Negara dan $\mathcal{X}$ eadilan \\ p-ISSN 2302-7010 e-ISSN 2721-9801}

Sedangkan dalam pasal 10 Peraturan Presiden Republik Indonesia Nomor 33 Tahun 2012 tentang Jaringan Dokumentasi dan Informasi Hukum Nasional di dalam :

'(1) Anggota JDIHN bertugas untuk melakukan pengelolaan dokumentasi dan informasi hukum yang diterbitkan oleh instansinya ;

'(2) Anggota JDIHN dalam melaksanakan tugas sebagaimana dimaksud pada ayat (1)menyelenggarakan fungsi :

'a. Pengumpulan, pengolahan, penyimpanan, pelestarian dan pendayagunaan informasi dokumen hokum yang diterbitkan instansinya;

'b. Pembangunan sistim informasi hokum berbasis teknologi informasi dan komunikasi yang dapat diintegrasikan dengan website pusat JDIHN ;

'c. Pembinaan dan pengembangan sumber daya manusia pengelola jaringan dan informasi hokum di lingkunganya ;

'd. Penyediaan sarana dan prasarana pengelolaan jaringan dokumentasi dan informasi hokum di lingkunganya ;

'e. Pelaksanaan evaluasi mengenai pengelolaan jaringan dokumentasi dan informasi hukum di lingkunganya sekurangkurangknya 1 (satu) kali dalam setahun ; dan

'f. penyampaian laporan setiap tahun di bulan desember kepada pusat JDIHN.

Sedangkan dalam pasal 11 Peraturan Presiden Republik Indonesia Nomor 33 Tahun 2012 tentang Jaringan Dokumentasi dan Informasi Hukum Nasional berbunyi :

Anggota JDIHN dalam melaksanakan tugas dan fungsi sebagaimana dimaksud dalam pasa 10 wajib berpedoman pada standar pengelolaan dokumentasi dan informasi hokum.

Dan dalam pasal 12 Peraturan Presiden Republik Indonesia Nomor 33 Tahun 2012 tentang Jaringan Dokumentasi dan Informasi Hukum Nasional berbunyi:

Anggaran kegiatan JDIHN dibebankan pada instansi masing-masing melalui anggaran pendapatan dan belanja Negara atau anggaran pendapatan dan belanja daerah dan/atau anggaran lainya sesuai dengan ketentuan peraturan perundang-undangan.

Bahwa dalam rangka melaksanakan pasal 7 Peraturan Presiden Republik Indonesia Nomor 33 Tahun 2012 tentang Jaringan Dokumentasi dan Informasi Hukum Nasional di tindaklanjuti dengan adanya regulasi baru yaitu Peraturan Menteri Dalam Negeri Republik Indonesia Nomor 2 Tahun 2014 tentang Pengelolaan Jaringan Dokumentasi dan Informasi Hukum Kementrian Dalam Negeri dan Pemerintah Daerah, aturan tersebut dalam rangka meningkatkan pelayanan kepada masyarakat atas kebutuhan dokumentasi dan informasi hokum secara lengkap, akurat, mudah dan cepat guna pengelolaan jaringan dokumentasi dan informasi hokum yang tertata dan terselenggara dengan baik. 


\section{Jurnal Negara dan Keadilan \\ p-ISSN 2302-7010 e-ISSN 2721-9801}

Bahwa JDIH Pemerintah Kabupaten/Kota berkedudukan di Bagian Hukum Sekretariat Daerah Kabupaten/kota, sedangkan pengelola JDIH dalam melakukan pengelolaan JDIH, meliputi :

'a. pengumpulan pengolahan, penyimpanan, penyebarluasan produk hokum ; dan

'b. penataan sistim informasi hokum melalui pemanfaatan teknologi informasi dan komunikasi.

Di dalam pasal 5 Peraturan Menteri Dalam Negeri Republik Indonesia Nomor 2 Tahun 2014 tentang Pengelolaan Jaringan Dokumentasi dan Informasi Hukum Kementrian Dalam Negeri dan Pemerintah Daerah berbunyi : impanan, penyebarluasan produkhukum sebagaimana dimaksud dalam pasal 4 huruf a,

'(1) Pengumpulan, pengelolaan, penyimpanan, penyebarluasan produkhukum sebagaimana dimaksud dalam pasal 4 huruf a, sekurang-kurangnya memuat :

'a. Tap MPR ;

'b. Undang-undang Republik Indonesia;

'c. Peraturan Pemerintah Republik Indonesia ;

'd. Peraturan Presiden ;

'e. Peraturan Menteri Dalam Negeri ;

'f. Peraturan Bersama Menteri Dalam Negeri ;

'g. Keputusan Menteri Dalam Negeri ;

'h. Peraturan Daerah Propinsi ;

'i. Peraturan Daerah Kabupaten/Kota ;

‘j. Peraturan Kepala Daerah Propinsi dan/atau Kabupaten/Kota ;

'k.Peraturan bersama Kepala Daerah Propinsi dan/atau Kabupaten/Kota;

'm. Informasi Hukum lainya.

'(2) Informasi Hukum lainya sebagaimana dimaksud pada ayat (1) huruf $\mathrm{m}$, sekurang-kurangnya meliputi :

hokum tetap ;

'a. Putusan badan peradilan yang telah mempunyai kekuatan

'b. Putusan mahkaman konstitusi ;

'c. Surat edaran menteri dalam neger ;

'd. MoU/Nota kesepakatan kementrian dalam negeri ;

'e. Klarifikasi peraturan Daerah ;

'f. Rancangan Produk Hukum ;

'g. Artikel Hukum ;

'h. Surat edaran kepala daerah propinsi dan/atau

kabupaten/kota;

'i. MoU/kerjasama antar daerah propinsi dan/atau kabupaten/kota ; dan/atau

'j. Rancangan peraturan daerah.

Sedangkan Di dalam pasal 6 Peraturan Menteri Dalam Negeri

Republik Indonesia Nomor 2 Tahun 2014 tentang Pengelolaan Jaringan Dokumentasi dan Informasi Hukum Kementrian Dalam Negeri dan Pemerintah Daerah berbunyi : 


\section{Jurnal Negara dan $\mathcal{X}$ eadilan \\ p-ISSN 2302-7010 e-ISSN 2721-9801}

(1) Penataan system informasi hokum sebagaimana dimaksud dalam pasal 4 huruf $b$, antara lain melalui :

'a. Sistem catalog;

'b. Sitim madiri/stand alone; dan

'c. sistim internet/website.

(2) Penataan system informasi hukum melalui sistim catalog sebagaiamana dimaksud pada ayat (1) huruf a, dikelola dengan cara merekam nformasi dokumen peraturan perundang-undangan yang berisi jenis, nomor, tanggal, judul, sumber dan status peraturan perundang-undangan ke dalam suatu unit computer ;

'(3) Penataan sistim informasi hokum melalui sistim mandiri/stand alone sebagaimana dimaksud pada ayat (1) huruf b dikelola melalui sistim aplikasi database peraturan perundangundangan yang berdiri sendiri dalam suati unit computer tanpa menggunakan jaringan ;

(4) Penataan sistim informasi hokum melalui sistim internet/website sebagaimana dimaksud pada ayat (1) huruf c di kelola melalui website :

'a. jdih.setjen.kemendagri.go.id dan kemendagri.go.id di lingkungan kementrian dalam neger ;

'b. jdih propinsi di lingkungan pemerintah propinsi, dan

'c. jdih kabupaten/kota di leingkungan pemerintah kabupaten/kota.

Adapun Di dalam pasal 7 Peraturan Menteri Dalam Negeri Republik Indonesia Nomor 2 Tahun 2014 tentang Pengelolaan Jaringan Dokumentasi dan Informasi Hukum Kementrian Dalam Negeri dan Pemerintah Daerah berbunyi:

'(1) Pemerintah propinsi melakukan penataan sistim informasi hokum website JDIH sebagaimana dimaksud dalam pasal 6 ayat (4) huruf b di lingkungan pemerintah propinsi ;

'(2) Pemerintah kabupaten/kota melakukan penataan sistim informasi hokum website JDIH sebagaimana dimaksud dalam pasal 6 ayat (4) huruf c di lingkungan pemerintah kabupaten/kota ;

'(3) Pemerintah propinsi dan kabupaten/kota yang telah melakukan penataan sistim informasi hokum website JDIH sebagaimana dimaksud pada ayat (1) dan ayat (2) melaporkan kepada sekretaris jendral kementrian dalam negeri paling lambat 7 hari kerja setelah website JDIH beroperasi/online ;

'(4) Pemerintah kabupaten/kota yang telah melakukan penataan sistim informasi hokum website JDIH sebagaimana dimaksud pada ayat (2) melaporkan kepada sekretaris daerah propinsi paling lambat 7 hari kerja setelah website JDIH beroperasi/online.

Sedangkan Di dalam pasal 8 Peraturan Menteri Dalam

Negeri Republik Indonesia Nomor 2 Tahun 2014 tentang 


\section{Jurnal Negara dan Keadilan \\ p-ISSN 2302-7010 e-ISSN 2721-9801}

Pengelolaan Jaringan Dokumentasi dan Informasi Hukum Kementrian Dalam Negeri dan Pemerintah Daerah berbunyi :

'(1) Pemerintah propinsi melakukan integrasi/link website JDIH kabupaten/kota di lingkunganmasing-masing kedalam website JDIH propinsi ;

'(2) Webesite jdih.setjen.kemendagri.go.id secara terintegrasi/link dengan website JDIH propinsi seluruh Indonesia.

Di dalam pasal 9 Peraturan Menteri Dalam Negeri Republik Indonesia Nomor 2 Tahun 2014 tentang Pengelolaan Jaringan Dokumentasi dan Informasi Hukum Kementrian Dalam Negeri dan Pemerintah Daerah telah menyebutkan :

'(1) pengelola JDIH sebagaimana dimaksud dalam pasal 3 paling sedikit 1 (satu) minggu sekali melakukan updating data produk hokum dan informasi hokum lainya sebagaimana dimaksud dalam pasal 5 untuk disebarluaskan dan di upload melalui website JDIH masing-masing.

'(2) Penyebarluasan informasi dan upload melalui website sebagaimana dimaksud pada ayat (1),setelah dilakukan pengkajian konsekuensi dan pengklasifikasian informasi.

Di dalam pasal 10 Peraturan Menteri Dalam Negeri Republik Indonesia Nomor 2 Tahun 2014 tentang Pengelolaan Jaringan Dokumentasi dan Informasi Hukum Kementrian Dalam Negeri dan Pemerintah Daerah telah menyebutkan :

'(1) Pengelola JDIH kabupaten/kota paling sedikit setiap 3 (t9ga) bulan sekali menyampaikan soft copy peraturan daerah kabupaten/kota, peraturan kepala daerah kabupaten/kota dan peraturan DPRD kabupaten/kota kepada pengelola JDIH propinsi masing-masing dan pengelola JDIH kementrian dalam negeri ;

'(2) Pengelola JDIH propinsi paling sedikit setiap 3 (tiga) bulan sekali menyampaikan soft copy peraturan daerah propinsi, peraturan kepala daerah provinsi dan peraturan DPRD propinsi kepada pengelola JDIH kementrian dalam negeri.

Sedangkan di dalam pasal 11 Peraturan Menteri Dalam Negeri Republik Indonesia Nomor 2 Tahun 2014 tentang Pengelolaan Jaringan Dokumentasi dan Informasi Hukum Kementrian Dalam Negeri dan Pemerintah Daerah telah menyebutkan :

'(1) pemohon informasi dapat mengunduh/download produk hokum daninformasi hukum sebagaimana dimaksud dalam pasa 5 melalui website jdih.setjen.kemendagri.go.id dan website kemendagri.go.id ;

'(2) pemohon informasi dapat mengunduh/download produk hokum dan informasi hokum sebagaimana dimaksud dalam pasal 5 melalui website JDIH di masing-masing propinsi dan kabupaten/kota. 


\section{Jurnal Negara dan Keadilan \\ p-ISSN 2302-7010 e-ISSN 2721-9801}

\section{PENUTUP}

Dalam rangka sebagai upaya untuk mewujudkan efektifitas pengelolaan jaringan dokumentasi dan informasi hukum, tentunya sangat diperlukan pembinaan dan pengawasan, untuk itu maka telah dituangkan ke dalam pasal 12 Peraturan Menteri Dalam Negeri Republik Indonesia Nomor 2 Tahun 2014 tentang Pengelolaan Jaringan Dokumentasi dan Informasi Hukum Kementrian Dalam Negeri dan Pemerintah Daerah. Adapun tujuan pembinaan dan pengawasan, maka telah dituangkan ke dalam pasal 13 Peraturan Menteri Dalam Negeri Republik Indonesia Nomor 2 Tahun 2014 tentang Pengelolaan Jaringan Dokumentasi dan Informasi Hukum Kementrian Dalam Negeri dan Pemerintah Daerah yang berbunyi : "pembinaan sebagaimana dimaksud dalam pasal 12 bertujuan untuk meningkatkan kualitas pengelolaan JDIH".

\section{DAFTAR PUSTAKA}

\section{Buku dan Makalah}

Chatib Rasyd, Kajian Yuridis Sosiologis dan Problematika Nikah Siri. Jepara, 6 Juni 2009

Grahamedia Press, 2014, Undang-Undang Republik Indonesia Nomor 1 Tahun 1974 Tentang Perkawinan, (Jakarta: Grahamedia Press.

Hilman Hadikusuma, 2007, Hukum Perkawinan Indonesia Menurut Perundangan, Hukum Adat, Hukum Agama, Cetakan II, Bandung: Andar Maju.

Karam Hilmi Farhat, 2007, Poligami dalam Pandangan Islam, Nasrani dan Yahudi, Jakarta: Darul Haj.

Lawrence M.Friedman, 2011, Sistem Hukum Perspektif Ilmu Sosial, Bandung:

Nusa Media.

\section{Peraturan Perundang-Undangan}

Undang-UndangNomor 1 Tahun1974 tentang Perkawinan

Undang-UndangNomor 23 Tahun2004 tentang Penanggulanga Kekerasan Dalam RumahTangga 